\title{
Exploring Approaches to Drivers and Barriers of Corporate Social Responsibility Implementation in Academic Literature
}

\author{
Vimala Govindasamy ${ }^{1,{ }^{*}, \text { Kalyani Suresh }}{ }^{2}$ \\ ${ }^{1,2}$ Department of Communication, Amrita School of Engineering, Coimbatore, Amrita Vishwa \\ Vidyapeetham [Amrita University], India
}

\begin{abstract}
CSR implementation is a relatively untapped area of study. Barriers are components that block and test the execution of CSR in an organization while drivers are positive CSR performance indicators. There is a dearth of academic literature of exploration of barriers and drivers of CSR in developing economies. This paper focuses on synthesizing existing scholarly research literature on drivers and barriers of Corporate Social Responsibility from the perspectives of developed and developing economies. With most companies around the world joining the CSR bandwagon in a bid to positively influence their relationships with employees and stakeholders, it is imperative that CSR research addresses the barriers and drivers that companies are likely to face during the implementation of their CSR strategies.
\end{abstract}

\section{Introduction}

Notions of CSR have undergone vast changes in the conception - while early definitions looked at CSR as a tool for maximizing profits for the company's shareholders, recent definitions position CSR as a tool for societal and organizational development. CSR is a self-regulating integrated business model that is also known as corporate conscience, corporate citizenship, social performance, or a sustainable responsible business. In 1990s, CSR began to be defined by terms such as corporate social performance (CSP), stakeholder theory, and business ethics theory $[1,2,3]$. Barriers are components that block and test the execution of CSR in an organization while drivers are positive CSR performance indicators.

\section{Theoretical Approach}

Notwithstanding the theoretical advice, in order to analysis the drivers and barriers, the concept of CSR should be understood. There are many definitions of corporate social responsibility (CSR). Drawing on an impressive history associated with the evolving definition and conceptualization of corporate social responsibility, [4] established for its

*Corresponding author: veemala21@gmail.com 
evolution and asserted that evidence of business community's concern for society has existed for centuries. The meaning of CSR may now also refer to activities which appear to advance a social agenda beyond that which is required by law (Siegel and Vitaliano, 2007)[5]. The definition may also include "responsible business practices related to sustainable economic growth and prosperity, social cohesion and equity, and environmental integrity and protection" [6].

Carroll's CSR are divided into four components; economic, legal, ethical and discretionary where an organization and they are required to fulfill all the four areas for CSR obligation. Philanthropic responsibilities is to be a good corporate citizen, ethical responsibilities, obligation to do what is right, fair and avoid any harm. Whereas for legal responsibilities is to obey the law, as they say the law is society's codification of right and wrong and lastly economic responsibilities is to be profitable and the foundation up which all others rest.

There are several definitions of institutional theory. An institutional theory of organization gives an affluent and intricate view of the organization. [7] has characterized institutional theory as components that assume an organization, either in a standard procedure or hierarchical structures. It could be sub-divided into two components either internal or external or qualities that may affect the decision making process either from the internal and external to the organization.

\section{Literature Review}

This paper focuses on synthesizing academic research literature on drivers and barriers of corporate social responsibility. With most companies around the world joining the CSR bandwagon in a bid to positively influence their relationships with employees and stakeholders; it is imperative that CSR research addresses the barriers and drivers that companies are likely to face during the implementation of their CSR strategies.

According to the study by Mirvis and Googins [8], generally all organizations are not in the same stages of corporate citizenship, but this can be explained by factors that can be divided into external pressures, or drivers and internal motivators, or drivers. The socioeconomic and socio-political factors are the external forces that influence the organization. Traditions and values are the internal motivators, or drivers and community and politics are external forces.

When it comes to the drivers for development there are instances the drivers come from the middle and up to the senior management, but in normal circumstances is from bottom to the top and vice versa. Essential internal drivers are company's image as well as a reputation for fostering CSR as expected by the international and the national society. The investment in a community is basically influenced by governmental and the community at large.

Motivations for pursing CSR practices by firms based on items selected from CSR studies $[9,10]$ were found to be primarily ethical and value orientated followed by enhancing profits and reputations and satisfying stakeholder demands. Graafland and Van [9] states that strategic motives and moral motives are the two important elements which motivate organizations to practice CSR.

There is a dearth of academic literature of exploration of barriers and drivers of CSR in developing economies. With reference to the corporate cultures of the West and South East Asia, according to Raman [11] majority of CSR oriented studies are Europe and the UScentric, while [12] and other authors such as $[13,14,15]$ discuss the shortage of theoretical and empirical literature available on the subject in the emerging economies.

Arevalo and Aravind [16] offer insights into models, motivations and barriers of CSR within Indian firms. They referred $[13,17,18]$ in the delineation of four models of social 
responsibility operating within Indian firms: the ethical (Gandhian) model; (focus on community welfare and ethical awareness) the statist (Nehruvian) (driven by legal requirement) model, the liberal [19] (focus on shareholder objectives) model and the stakeholder [20] model (stakeholder centric-focus). They categorized these motivators as caring versus profit driven or moral versus strategized. Their study also revealed the most significant barriers in the implementation of CSR study by Indian firms were insufficient resources (training and financial), lack of management support and training.

According to Mitra [21] despite the above scholars attesting to the four operational models of CSR the latest Indian context strongly focuses on a neoliberal profit centered model. Mitra [21] deals with a CSR discourse from the point of view of culture-centered approach (CCA) and outlines five motivations of CSR namely nation-building façade, underlying neoliberal logics, CSR as voluntary, CSR as synergistic, and a clear urban bias. (p. 131).

However, he integrates main stream CSR discourse through the culture - (e.g. faith, Swadeshi, Swaraj, Ahimsa, Ghandian ethics) - structure (state policy, organizational strategic, global/local flows) - agency (Subaltern, reframing of institutional responsibility etc.) triad of CCA. This study opens up the vast gap in the literature in terms of social reality and corporate rhetoric and highlights an alternative view of interpreting culture, business and society relations. Few studies examine barriers of CSR implementation with national approach.

Valmohammadi [22] investigated the concepts in an Iranian context pertaining to the understanding of CSR domain alongside with the analysis of CSR drivers and barriers. Iran is not prepared or responsive to CSR at the moment. However, they could see CSR emerges as an opportunity over the years. Respondents in the study revealed that CSR as the "forgotten element of businesses in Iran". For instance, community welfare and organization conscious, branding and image, profitability is constantly referred as CSR drivers. Therefore, environmental preservation, quality improvement and customer retention are the prominent key drivers.

In this study, Valmohammadi, [22] concentrates on the ISO 26000," code of conduct and contracts his investigation to seven intensive issues (supported by 105 feedback acquired from Iranian organizations): authoritative administration, human rights, work practices, the environment, reasonable working practices, end-users issues, and public participation and advancement.

Meanwhile, [23] recorded CSR perceptions among Bangladeshi managers, and CSR endeavours and barriers were investigated through face-face interviews. Perceived barriers fell under three categories, i.e. psychological, moral and systemic, with least important being systemic.

Further, [24] present results from 23 semi-structured interviews with senior corporate managers from Bangladeshi organizations on social reporting in Bangladesh and concentrate in particular on the non- disclosure on three issues: child labour, equal opportunities and poverty alleviation. The findings suggest that the main barriers to CSR non-disclosure are low resources, the profit angle, lack of knowledge about legal requirements, bad performance and the fear of bad publicity.

Nevertheless, [25] try to bridge the gap in existing Southeast Asian academic literature on barriers to CSR in the textile industry. They identify 12 common barriers as lack of stakeholder awareness, lack of training, lack of information, financial constraints, lack of customer awareness, lack of concern for reputation, lack of knowledge, lack of regulation and standards, diversity, company culture, lack of social audit, and lack of top management commitment. They propose and apply a model framework using fuzzy multi-criteria decision making (MCDM) to reveal the relatively most important barrier in the Indian textile sector as financial constraints and the least as diversity. 
One way to deal with recognizing CSR barriers is to associate them to a firm's size. A study by Laudal, (2011)[26], investigating the Norwegian clothing sector, examined the drivers and barriers of CSR and then differentiated the changes of these elements within the SMEs and MNEs. His study found that in terms of public policy, the main focus for SMEs should be ensuring their CSR performance capabilities. Firms in the process of transition between an SME and an MNE should focus on strengthening market incentives for CSR and to disseminate best practices. As for large MNEs, cementing partnerships between governments and business representatives for furthering long-term interests, gains importance.

With the help of literature reviews and semi-organized meetings, [27] investigated the possibilities and barriers of CSR in Irish origin. He likewise contrasts the circumstances of both possibilities and barriers of CSR between big organizations and SMEs.

According to Mont and Leire [28] investigated the CSR drivers in supply chains from the perspective of Swedish corporate. Internal drivers ranged from risk reduction, protecting brand name, peaceful working environment for preserving the national image internationally, while the external drivers typically were fulfilling stakeholder (NGO, media) expectations, external evaluation and rating, reporting on sustainability issues.

Early literature on CSR in Malaysia [29, 30], suggested that CSR in Malaysia was still in the early stages. Active communication about CSR did not match awareness about it. It is believed that CSR practices were introduced to Malaysia through multinational organizations [31]. Post-independence, Malaysia was dependent on foreign investment, and joined the CSR fad. This was a major driver for adoption of CSR in Malaysia [32].

A 2013 report by UNICEF Malaysia (UNICEF Malaysia, 2013)[33] on the Malaysian government's implementation of Vision 2020 outlines four CSR related strategic challenges: (i) establishing a fully moral and ethical society, (ii) establishing a fully caring society and a caring culture, (iii) ensuring an economically just society, and (iv) establishing a prosperous society, with an economy that is fully competitive dynamic, robust and resilient. CSR policies and practices in Malaysia have shown tremendous participation from various sectors which include the Malaysian government, Bursa Malaysia and Companies Commission of Malaysia to create awareness and encourage companies to promote CSR in their business community and environment to uplift the status of CSR.

Based on [34] in their study identify internal and external enablers of CSR in sustainable supply chain practices in the Malaysian context as people's issues; strategic issues and functional issues internal drivers include management commitment and employee involvement, competitive advantage, reputation and risk management, organization size, purchasing and supply. External drivers include government, customers, suppliers, investors and NGOs. Internal barriers are lack of management commitment, resource costs, and lack of training. External barriers are listed as government, customers, media organizations and technology.

Table 1. Summary of CSR drivers and barriers identified by academics

\begin{tabular}{|l|l|c|}
\hline \multicolumn{1}{|c|}{ Author } & \multicolumn{1}{|c|}{ CSR drivers and barriers } & $\begin{array}{c}\text { Country in } \\
\text { context }\end{array}$ \\
\hline $\begin{array}{l}\text { Grafland and van de } \\
\text { Ven, (2006) and } \\
\text { Hemingway and } \\
\text { Maclagan, (2004) }\end{array}$ & $\begin{array}{l}\text { Strategic and moral motivators - ethics, } \\
\text { values, profit orientation, reputation, } \\
\text { satisfying stakeholders. }\end{array}$ & Netherlands \\
\hline $\begin{array}{l}\text { Mirvis and Googins, } \\
\text { (2006) }\end{array}$ & $\begin{array}{l}\text { Companies at different stages of CSR } \\
\text { implementation have different external } \\
\text { (government and society) and internal } \\
\text { (company image) motivating forces }\end{array}$ & Finland \\
\hline
\end{tabular}




\begin{tabular}{|c|c|c|}
\hline & affecting them. & \\
\hline $\begin{array}{l}\text { Belal and Owen } \\
\text { (2007) }\end{array}$ & $\begin{array}{l}\text { Main barriers - non-disclosure, low } \\
\text { resources, the profit angle, lack of } \\
\text { knowledge about legal requirements, bad } \\
\text { performance and the fear of bad publicity. }\end{array}$ & Bangladesh \\
\hline Sweeney, (2007) & $\begin{array}{l}\text { Possibilities and barriers of CSR in Irish } \\
\text { origin. Contrast the circumstances of both } \\
\text { possibilities and barriers of CSR between } \\
\text { big organizations and SMEs. }\end{array}$ & $\begin{array}{c}\text { United } \\
\text { Kingdom }\end{array}$ \\
\hline $\begin{array}{l}\text { Amran and Susela, } \\
2008\end{array}$ & $\begin{array}{l}\text { Driver - post-independent Malaysia } \\
\text { dependent on foreign investment, and } \\
\text { joined the CSR fad. }\end{array}$ & Malaysia \\
\hline $\begin{array}{l}\text { Mont and Leire, } \\
\text { (2009) }\end{array}$ & $\begin{array}{l}\text { Drivers in supply chains - internal drivers - } \\
\text { risk reduction, protecting brand name, } \\
\text { peaceful working environment for } \\
\text { preserving the national image international; } \\
\text { external drivers - fulfilling stakeholder } \\
\text { (NGO, media) expectations, external } \\
\text { evaluation and rating, reporting on } \\
\text { sustainability issues. }\end{array}$ & Sweden \\
\hline $\begin{array}{l}\text { Duarte and Rahman, } \\
\text { (2010) }\end{array}$ & $\begin{array}{l}\text { Perceived barriers fell under three } \\
\text { categories, i.e. psychological, moral and } \\
\text { systemic with least important being } \\
\text { systemic. }\end{array}$ & Bangladesh \\
\hline $\begin{array}{l}\text { Arevalo and Aravind, } \\
\text { (2011) referring to } \\
\text { Balasubramaniam } \\
\text { et.al. (2005), Mehta } \\
\text { et.al. (2006) and } \\
\text { Kumar et. al. (2011) }\end{array}$ & $\begin{array}{l}\text { Motivations and barriers of CSR within } \\
\text { Indian firms - Motivators - Moral versus } \\
\text { Strategic/caring versus Profit driven. } \\
\text { Barriers - insufficient resources (training } \\
\text { and financial), lack of management support } \\
\text { and training. }\end{array}$ & India \\
\hline $\begin{array}{l}\text { Valmohammadi, } \\
\text { (2011) }\end{array}$ & $\begin{array}{l}\text { CSR as the "forgotten element of businesses } \\
\text { in Iran". Prominent key drivers are } \\
\text { environmental preservation, quality } \\
\text { improvement and customer retention. }\end{array}$ & Iran \\
\hline Laudal (2011) & $\begin{array}{l}\text { Norwegian clothing sectors, examined the } \\
\text { CSR drivers and barriers and differentiated } \\
\text { the changes of these elements within the } \\
\text { SMEs and MNEs. }\end{array}$ & Norway \\
\hline Mitra, (2012) & $\begin{array}{l}\text { Culture-centered approach (CCA). Outline } \\
\text { five motivations - nation-building façade, } \\
\text { underlying neoliberal logics, CSR as } \\
\text { voluntary, CSR as synergistic, and a clear } \\
\text { urban bias. Strong focus on the neoliberal } \\
\text { profit centered model. }\end{array}$ & India \\
\hline $\begin{array}{l}\text { Shen, Govindan, and } \\
\text { Shankar (2015) }\end{array}$ & $\begin{array}{l}\text { Barriers in the textile industry - lack of } \\
\text { stakeholder awareness, lack of training, lack } \\
\text { of information, financial constraints, lack of } \\
\text { customer awareness, lack of concern for } \\
\text { reputation, lack of knowledge, lack of } \\
\text { regulation and standards, diversity, } \\
\text { company culture, lack of social audit, and } \\
\text { lack of top management commitment. }\end{array}$ & $\begin{array}{l}\text { Southeast } \\
\text { Asian }\end{array}$ \\
\hline $\begin{array}{l}\text { Tay, Rahman, Aziz, } \\
\text { and Sidek, (2015) }\end{array}$ & $\begin{array}{l}\text { Identify internal and external enablers in } \\
\text { sustainable supply chain as - people's } \\
\text { issues; strategic issues and functional }\end{array}$ & Malaysia \\
\hline
\end{tabular}




\begin{tabular}{|l|l|}
\hline $\begin{array}{l}\text { issues. Internal drivers - management } \\
\text { commitment and employee involvement, } \\
\text { competitive advantage, reputation and risk } \\
\text { management, organization size, purchasing } \\
\text { and supply. External drivers - government, } \\
\text { customers, suppliers, investors and NGOs. } \\
\text { Internal barriers - lack of management } \\
\text { commitment, resource costs, and lack of } \\
\text { training. External barriers - government, } \\
\text { customers, media organizations and } \\
\text { technology. }\end{array} \mid$ \\
\hline
\end{tabular}

\section{Conclusion}

A synthesis of literature available on drivers and barriers in CSR implementation in the West reveals a vast gap in the literature in terms of social reality and corporate rhetoric, scholarly research in Southeast Asia the need for highlighting an alternative view of interpreting drivers and barriers to implementation of CSR taking into account the business, culture, and society triad in which the corporation is situated. This study also comprehends that the drivers and barriers of CSR vary according the size of corporations and the strategic versus moral motives adopted by them in the pursuance of CSR.

\section{References}

1. Porter, M. Kramer, Strategy and Society: The link between Competitive Advantage and Corporate Social Responsibility. Harv. Bus Rev. Dec; 84(12): 78:92, 163 (2006)

2. C.B. Bhattacharya, D. Korschun \& S. Sen, "Strengthening Stakeholder-Company RelationshipsThrough Mutually Beneficial Corporate Social Responsibility Initiatives" S. J Bus Ethics 85:257. doi: 10.1007/S10551-008-9730-3, (2009)

3. D. Jamali, A stakeholder approach to corporate social responsibility: A fresh perspective into theory and practice. J Bus Ethics 82:213. doi: 10.1007/s10551-0079572-4 (2008)

4. A. Carroll, A. Corporate Social Responsibility: Evolution of a definitional construct. Bus Soc 38(3): 268-295. (1999)

5. D.S. Siegel, D.F. Vitaliano. An empirical analysis of the strategic use of corporate social responsibility. J. of Econ. and Mgmt. Strgy., 16(3), 773-792 (2007)

6. N.A. Torugsa, W. O'Donohue, R. Hecker. Proactive CSR: An Empirical Analysis of the role of its economic, social and environmental dimensions on the association betweencapabilities and performance. J Bus Ethics 115:383, doi: 10.1007/s10551-0121405-4 (2013)

7. L.G. Zucker, Institutional Theories of Organisation. Annu. Rev. So. Vol 13:443-464, doi: 10.1146/annurev.so.13.080187.002303 (1987)

8. P. Mirvis, B. Googins, Stages of Corporate Citizenship: A Development Framework. Cal. Mgmt. Rev. 48:2, pp.03-126 (2006)

9. J. Graafland, B. van de Ven, Strategic and moral motivation for corporate social Responsibility. J. of Corp.Ctznship., 22:111-123, (2006)

10. C.A. Hemingway, P.W. Maclagan, Managers' personal values as drivers of corporatesocial responsibility. J. Bus Ethics Vol. 50(1):33-44 (2004)

11. S.R. Raman, Corporate social responsibility in India: a view from the top. Gobal Bus Rev. Vol. 7(2):313-24 (2006) 
12. B. Arora, R. Puranik, "A review of corporate social responsibility in India", Society for International Development. Vol. 47(3): 93-100 (2004)

13. N.K..Balasubramanian, D. Kimber, F. Siemensma, Emerging opportunities or traditions reinforced?', J. of Corp. Ctzship., Vol. 17:79-92 (2005)

14. M. Mitra, It's only business! India's corporate social responsiveness in a globalized world. New Delhi, India: Oxford Uni. Press (2007)

15. M. Narwal, T. Sharma, "Perceptions of corporate social responsibility in India: An Empirical study”. J. of Knowledge Globalization Vol. 1:61-79 (2008)

16. J.A. Arevalo, D. Aravind, D. "Corporate social responsibility practices in India: approach, drivers, and barriers”, C.G. Vol. 11(4): 399-414 (2011)

17. Mehta, V., John, P., Kumar, A., Maitra, I., Puranik, R., Shrivastava, S., et al. Delivering value: An exploration of community development vehicles adopted by corporate in India. New Delhi: Partners in Change (2006)

18. R. Kumar, D. Murphy, V. Balsari, "Altered images: the 2001 state of corporate social responsibility in India”. Business-Social Partnership: Beyond Philanthropy Conference IAM Calcutta, India, Dec. (2011)

19. M. Friedman, The social responsibility of business is to increase profits. The NY Times Mag., September 13:32-33 (2007)

20. R.E. Freeman, Strategic Management: A Stakeholder Approach, Pitman Series in Bus And Public Policy, Boston, MA.

21. M. Mitra, "My Country's Future”: A Culture-centered Interrogation of CSR in India.J. Bus. Ethics (2012) 106:131-147. doi:10.1007/ss10551-011-0985-8. Recd. 29 July 2009/Accepted:21 July 2011/Pub. online: 4 Aug. 2011@Springer Science+ Bus. Media B.V. (2011 and 2012)

22. C.Valmohammadi, 'Investigating corporate social responsibility practices in Iranian organisations: an ISO 26000 perspective'. Bus. Strgy. Series, Vol. 12(5): 257-263 (2011)

23. F.P. Duarte, S. Rahman, Perceptions of corporate social responsibility by Bangladeshi Managers: An exploratory study. Int. Rev. Bus. Res. Pap. 6(5), 119-136 (2010)

24. A.R. Belal, D.L. Owen, "The views of corporate managers on the current state of, and future prospects for, social reporting in Bangladesh: An engagement-based study”, Accting, Auditing \& Acctbility J. Vol. 20(3): 472-494 (2007)

25. L. Shen, K. Govindan, M. Shankar, Evaluation of barriers of corporate social responsibility using an analytical hierarchy process under a fuzzy environment - A Textile Case, Sustainability 7 (3):3493-3514; doi: 10.3390/su7033493 (2015)

26. T. Laudal, Drivers and barriers of CSR and the size and internationalization of firms. Soc. Responsib. J. 7: 234-256 (2011)

27. L. Sweeney, Corporate Social Responsibility in Ireland: barriers and opportunities experienced by SMEs when undertaking CSR. Corp. Gov.: The Int. J. of Bus. In Soc. 7 (4): 516-523 (2007)

28. O. Mont, C. Leire, "Socially responsible purchasing in the supply chain: drivers and barriers in Sweden". Soc. Responsib. J. 5 (3): 388-407 (2008)

29. AB. Amran, S.S. Devi, Corporate social reporting in Malaysia: An institutional perspective. WREMSD Vol. 3(1): 20-36 (2007)

30. M. Nejati, A. Amran. CSR and SMEs: Exploratory study on motivations from a Malaysian perspective. Bus. Strategy Series 10 (5): 259-265 (2009)

31. A. Amran, M.M. Zain, M. Sulaiman, T. Sarker, S.K. Ooi, Empowering society for better corporate social responsibility (CSR): The case of Malaysia. (2013)

32. A. Amran, S.Susela Devi, The impact of government and foreign affiliate influence on corporate social reporting: The case of Malaysia. Mgrial Auditing J. 23(4):386-404 (2008) 
33. UNICEF Malaysia, Corporate Social Responsibility Policies in Malaysia: Enhancing the child focus. Unite for children retrieved from

http://www.unicef.org/malaysia/Unicef_CSR_Msia_110713_lowres.pdf on 30.08.2015 (2013)

34. M.Y. Tay, A.A. Rahman, Y.A. Aziz, S. Sidek, A Review on Drivers and Barriers towards Sustainable Supply Chain Practices. Int. J. of Soc. Sci. and Humanity, Vol. 5 (10): 892-897 (2015) 